\title{
Therapeutic Window of Stem Cell Potential for Targeting Pediatric Malignant Brain Tumors: An Opportunity for Stem Cell Therapy
}

\author{
Shengwen Calvin Li • Yuan-Ping Han • \\ Brent A. Dethlefs • William Günter Loudon
}

Published online: 23 April 2009

(C) Humana Press 2009

This article has been published OnlineFirst, but is withdrawn due to having been rejected for publication by the Editor in Chief. The publisher regrets the error.

\footnotetext{
This article has been published OnlineFirst, but is withdrawn due to having been rejected for publication by the Editor in Chief. The publisher regrets the error.

S. Calvin Li $(\bowtie) \cdot$ B. A. Dethlefs $\cdot$ W. Günter Loudon Neuro-Oncology Research Laboratory,

Center for Neuroscience and Stem Cell Research,

CHOC Children's Research Institute,

455 S. Main Street,

Orange, CA 92868-3874, USA

e-mail: sli@choc.org

S. Calvin $\mathrm{Li}$

Department of Neurology, University of California,

Irvine, CA 92697, USA

W. Günter Loudon

Department of Neurological Surgery, University of California,

Irvine, CA 92697, USA

S. Calvin $\mathrm{Li}$

Department of Biological Science, California State University,

Fullerton, CA 92834, USA

S. Calvin $\mathrm{Li}$

Center for Stem Cell Biology and Regenerative Medicine,

Thomas Jefferson University,

Philadelphia, PA 19107, USA

Y.-P. Han

Department of Surgery, Keck School of Medicine,

University of Southern California,

Los Angeles, CA 90033-4680, USA
} 